\title{
Pengukuran Keberhasilan Penggunaan Internet banking di Bank Rakyat Indonesia Kota Denpasar
}

\author{
A.A. Putri Pintari Dewi ${ }^{1}$ \\ Made Gede Wirakusuma ${ }^{2}$ \\ Gayatri $^{3}$ \\ 1,2,3Fakultas Ekonomi dan Bisnis Universitas Udayana, Indonesia \\ ${ }^{*}$ Correspondences : putri.pintari21@yahoo.com
}

\begin{abstract}
ABSTRAK
Penelitian ini menilai keberhasilan penggunaan internet banking menggunakan model DeLone \& McLean (D\&M) dengan tujuan untuk mengukur keberhasilan penggunaan teknologi internet banking. Penelitian dilakukan pada Bank Rakyat Indonesia (BRI) Kota Denpasar dengan 150 orang pengguna internet banking sebagai responden yang dipilih melalui teknik accidental sampling. Hasil pengujian menunjukkan kualitas informasi, kualitas sistem informasi, kualitas layanan berpengaruh positif pada minat penggunaan internet banking dan minat penggunaan berpengaruh positif pada net benefit. Implikasi dari penelitian ini mencakup dua hal, yaitu implikasi teoritis dan implikasi praktis, pada implikasi teoritis kualitas informasi, kualitas sistem informasi, kualitas layanan dan minat pengguna berpengaruh pada net benefit atau manfaat bersih menggunakan internet banking. Implikasi praktis adalah tingginya minat penggunaan internet banking dapat menciptakan net benefit untuk para nasabah PT Bank Rakyat Indonesia Kota Denpasar.
\end{abstract}

Kata Kunci: Model D\&M; Kesuksesan Penggunaan Sistem; Internet banking.

\section{Measurement of the Successful Use of Internet banking at Bank Rakyat Indonesia Denpasar City}

ABSTRACT

This study assesses the success of using internet banking using the DeLone \& McLean (DEM) model with the aim of measuring the success of using internet banking technology. The research was conducted at Bank Rakyat Indonesia (BRI) Denpasar City with 150 internet banking users as respondents who were selected through accidental sampling technique. The test results show that the quality of information, the quality of information systems, the quality of service has a positive effect on the interest in using internet banking and the interest in using it has a positive effect on the net benefits. The implications of this research include two things, namely ensuring and improving the experience, quality of information, quality of service and user interest in the net benefits or net benefits of using internet banking. The high practical implication is that the interest in using internet banking can create net benefits for customers of PT Bank Rakyat Indonesia Denpasar City.

Keywords: DEM Models; Successful Use of the System; Internet banking.

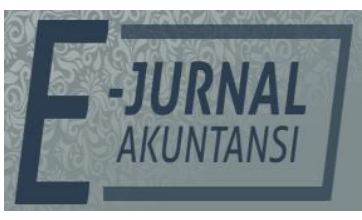

e-ISSN 2302-8556

Vol. 32 No. 2

Denpasar, Februari 2022

Hal. 295-311

DOI:

10.24843/EJA.2022.v32.i02.p02

PENGUTIPAN:

Dewi, A. A. P. P. \&

Wirakusuma, M. G. (2022).

Pengukuran Keberhasilan

Penggunaan Internet banking di Bank Rakyat Indonesia

Kota Denpasar.

E-Jurnal Akuntansi, 32(2), 295-311

RIWAYAT ARTIKEL:

Artikel Masuk:

25 November 2021

Artikel Diterima:

10 Januari 2022

Artikel dapat diakses : https://ojs.unud.ac.id/index.php/Akuntansi/index 


\section{PENDAHULUAN}

Pada era teknologi yang berkembang pesat, pelayanan perbankan dituntut lebih cepat, mudah dan fleksibel. Pesatnya pertumbuhan internet merubah cara perusahan terhubung dengan konsumennya, tidak terkecuali bisnis perbankan. Sejak penggunaan internet sebagai media belanja masih menjadi hal utama, penyedia layanan perbankan juga perlu untuk memprediksi penerima internet oleh konsumen, dan mengerti mengapa penggunaan tersebut masih dilakukan. Konsumen lebih memilih layanan internet karena mereka tidak perlu bertemu langsung dengan penyedia layanan secara personal dan berhadapan dengan perilaku dari konsumen lainnya (Rithmaya, 2016). Peran teknologi informasi menjadi salah satu fasilitas utama perusahaan untuk menghasilkan informasi yang berkualitas yang sekaligus menjadi salah satu strategi bisnis bagi perusahaan. Kelebihan penggunaan sistem informasi berbasis komputer adalah data yang disajikan akan lebih cepat, tepat dan akurat (Oktariyana, 2019).

Internet banking, yaitu layanan perbankan yang dilakukan melalui aplikasi internet banking yang terhubung internet (Dewi, 2016). Internet banking adalah salah satu pelayanan jasa bank yang memungkinkan nasabah untuk memperoleh informasi, melakukan komunikasi dan melakukan transaksi perbankan melalui jaringan internet, dan bukan merupakan bank yang hanya menyelenggarakan layanan perbankan melalui internet. PT Bank Rakyat Indonesia merupakan salah satu perusahaan BUMN dan penyedia jasa keuangan yang ada di seluruh Indonesia salah satunya pulau Bali. PT Bank Rakyat Indonesia dipilih dalam penelitian ini dikarenakan Bank ini merupakan salah satu terbesar milik pemerintah Indonesia. Bank milik pemerintah Bank sebagai lembaga yang bergerak dalam bidang jasa keuangan sudah seharusnya meningkatkan pertumbuhan pengguna internet banking, Keberhasilan internet banking tergantung dari bagaimana nasabah menerima sistem tersebut. Oleh karena itu, penting bagi pihak bank untuk mengetahui bagaimana para konsumennya mengapresiasi jasa internet banking agar dapat membantu menemukan rencana strategis dan meningkatkan pangsa pasar.

Berdasarkan data yang diperoleh dari Bank Rakyat Indonesia Kantor Cabang Denpasar Renon, pengguna internet banking mengalami peningkatan dari tahun 2018 sampai tahun 2020. Dengan demikian, penting bagi pihak bank untuk mengetahui bagaimana pengukuran keberhasilan penerapan pengguna internet banking pada Bank Rakyat Indonesia Kantor Cabang Denpasar. Penerapan sistem teknologi informasi yang diharapkan pada suatu organisasi adalah kesuksesan dari sistem teknologi informasi tersebut dalam pelaksanaanya (Dewi, 2016). Banyak penelitian telah dilakukan untuk mengidentifikasi faktor-faktor yang menyebabkan kesuksesan sistem teknologi informasi. Salah satunya yang paling terkenal adalah penelitian yang dilakukan oleh DeLone \& McLean (1992). Model kesuksesan sistem informasi dari DeLone \& McLean (1992) ini merupakan model yang sederhana dan dinilai cukup valid. Seiring dengan berkembangnya penelitian mengenai sistem informasi. Model yang dikembangkan oleh DeLone \& McLean ini mendapatkan berbagai kritik dan saran. Kontribusi penelitianpenelitian sebelumnya dan akibat perubahan-perubahan dari peran dan penanganan sitem informasi yang telah berkembang maka DeLone \& McLean 
(2003) memperbarui modelnya dan menyebutnya sebagai Updated DEM IS Success Model.

Pengukuran keberhasilan sistem informasi yang dalam penelitian ini yaitu para pengguna Internet banking mengacu pada model kesuksesan sistem informasi yang diperbarui dari DeLone \& McLean (2003). Updated DEM IS Success Model yang dikembangkan oleh DeLone \& McLean (2003) menjelaskan bahwa terdapat tujuh faktor atau komponen dalama mengukur kesuksesan sistem informasi, antara lain kualitas sistem (system quality), kualitas informasi (information quality), kualitas pelayanan (service quality), minat memakai (intention tu use), pemakaian (use), kepuasan pemakai (user satisfaction), dan manfaat bersih (net benefits). Pengukuran keberhasilan internet banking menggunakan lima faktor yang terdapat pada model DeLone \& McLean (2003), yaitu kualitas sistem (system quality), kualitas informasi (information quality), kualitas pelayanan (service quality) dan menambahkan dimensi minat untuk menggunakan (intention to use) sebagai alternatif dari dimensi penggunaan (use), serta menggunakan manfaat bersih (net benefits).

Pada Model DeLone \& McLean (1992), minat untuk menggunakan sistem informasi ditentukan oleh kualitas informasi, kualitas sistem, dan kualitas layanan. Pengguna merasakan bagaimana sebuah sistem memberikan kemudahan-kemudahan yang bermanfaat yang mempengaruhi minat penggunaan serta menghubungkannya dengan manfaat bersih (net benefit). Kualitas informasi menjadi predictor pada kualitas layanan dari internet banking. Kualitas sistem menjadi prediktor besaran teknologi komputer dirasakan relatif mudah untuk dipahami dan digunakan. Kualitas layanan sebagai prediktor penilaian menyeluruh atas keunggulan suatu pelayanan yang diberikan internet banking.

Penelitian ini menguji keberhasilan sebuah sistem dengan menggunakan model DeLone \& McLean (1992) yang merupakan ukuran dari faktor teknologi. Penelitian ini berfokus pada penggunaan internet banking. Internet banking akan terus menyesuaikan dengan perubahan perkembangan teknologi di era modern ini guna memenuhi harapan nasabah Bank BRI Cabang Kota Denpasar. Lokasi penelitian dipilih pada Bank BRI Cabang Kota Denpasar karena, di Kota Denpasar memiliki pertumbuhan ekonomi yang sangat pesat, sehingga dapat mempermudah nasabahnya khususnya nasabah yang berada di kota Denpasar dalam melakukan semua transaksi perbankan seperti transfer uang, cek saldo, akses produk perbankan seperti membuka tabungan berjangka, deposito, pinjaman KTA/KMG/KPR secara online dengan mudah dan cepat, cek nilai tukar mata uang (kurs) rupiah terhadap mata uang negara lain dan Update dengan berbagai program dan produk terkini dari Bank.

Tujuan penelitian ini Untuk mendapatkan bukti empiris pengaruh kualitas sistem, kualitas informasi, dan kualitas pelayanan pada minat penggunaan serta pengaruh minat penggunaan pada net benefit internet banking Bank Rakyat Indonesia di Kota Denpasar, penelitian ini nantinya akan berkontribusi pada ilmu pengetahuan dalam penambahan kajian pendukung penelitian selanjutnya dan berkontribusi pada pihak perbankan terkait net benefit internet banking. 


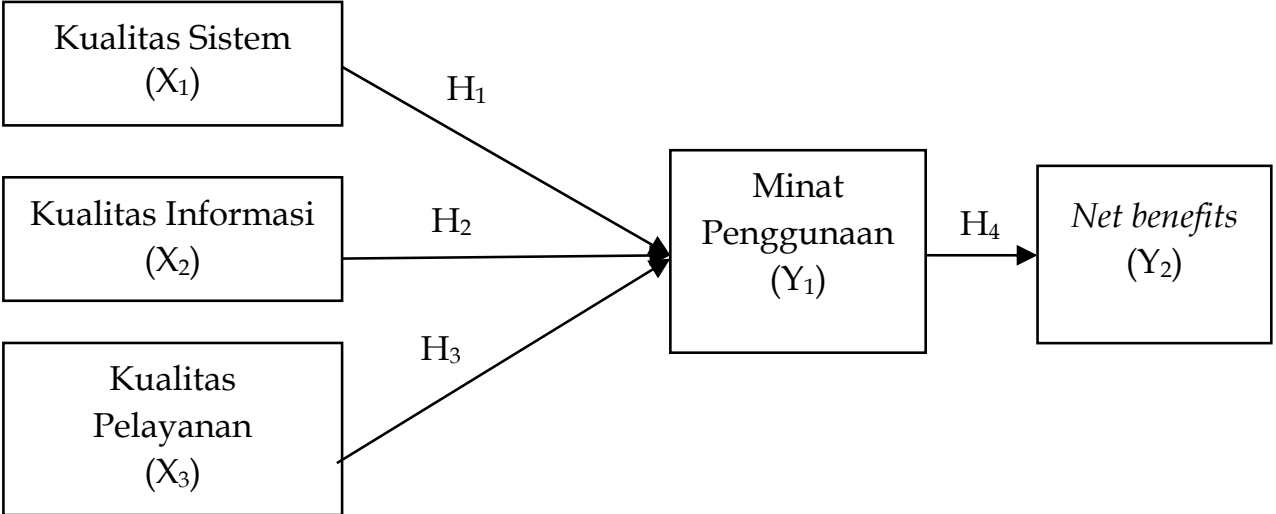

Sumber: Data Penelitian, 2021

Gambar 1. Konsep Penelitian

Teori yang melandasi penelitian ini adalah teori perilaku dari Davis et al. (1989) mengemukakan bahwa perilaku seseorang merupakan ekspresi dari keinginan atau minat seseorang dimana keinginan tersebut dipengaruhi faktorfaktor sosial, perasaan dan konsekuensi yang dirasakan mengemukakan bahwa adanya manfaat yang dirasakan oleh pemakai sistem informasi akan mningkatkan minat mereka untuk menggunakan sistem informasi. Menurut Davis et al. (1989), net benefits adalah keuntungan atau manfaat bersih yang dirasakan individu dan organisasi setelah menerapkan sistem informasi. Hubungan minat pemanfaatan, penggunaan sistem informasi, perilaku penggunaan teknologi informasi (use behavior) merupakan intensitas dan atau frekuensi pemakai dalam menggunakan teknologi informasi.

Kualitas informasi dapat diartikan sebagai kualitas dari informasi yang merupakan hasil pengolahan data. Informasi yang berkualitas setidaknya memenuhi empat criteria yaitu akurat, tepat pada waktunya, relevan, dan lengkap (Dewi, 2016). Begitu pula dengan informasi yang didapatkan dari pengguna internet banking. Tinggi rendahnya kualitas informasi akan berpengaruh terhadap penggunaan teknologi oleh karyawan. Semakin tinggi kualitas informasi yang didapat karyawan, semakin tinggi pula tingkat penggunaan teknologi informasi. DeLone \& McLean (2003) menemukan hubungan anatara kualitas informasi pada minat untuk menggunakan sistem informasi. Informasi dengan kualitas terbaik akan meningkatkan kegunaan persepsian pengguna dan meningkatkan penggunaan sistem informasi.

Kualitas informasi merupakan tingkat dimana karakteristik yang memberikan nilai bagi pengguna (user). Ukuran minat penggunaan pada sistem informasi dicerminkan oleh kualitas informasi yang dihasilkan oleh suatu sistem. Minat penggunaan terhadap suatu sistem informasi adalah bagaimana cara pemakai memandang sistem informasi secara nyata, bukan pada kualitas sistem secara teknik (Buchholz \& Rübbelke, 2020; Rukmiyati \& Budiartha, 2016). Jika pengguna sistem informasi percaya bahwa informasi yang dihasilkan dari sistem itu optimal, mereka akan menggunakan sistem tersebut.

Penelitian-penelitian yang menggunakan konstruk dari D\&M IS Success Model menunjukkan pengaruh positif anatara kualitas informasi pada minat penggunaan, yaitu penelitian yang dilakukan oleh Admaja (2014), Utami dan Samopa (2013), Supriyono (2017) dan Oktariyana (2019), Lau \& Chen (2021). 
Berbeda dengan penelitian yang dilakukan oleh Nurlani \& Permana (2017) yang menunjukkan faktor teknologi yaitu kualitas informasi, kualitas sistem dan kualitas layanan tidak terbukti signifikan terhadap minat penggunaan.

Berdasarkan uraian diatas dikatakan bahwa jika pemakai sistem informasi percaya bahwa jika informasi yang dihasilkan dari sistem relevan, akurat, tepat waktu, dan dapat dipercaya, maka akan meningkatkan minat menggunakan sistem tersebut. Berdasarkan uraian tersebut maka dirumuskan hipotesis sebagai berikut.

$\mathrm{H}_{1}$ : Kualitas informasi berpengaruh positif pada minat penggunaan internet banking.

DeLone \& McLean (1992) mengasumsikan bahwa kualitas sistem dan kualitas informasi, secara individual dan bersama-sama mempengaruhi minat penggunaan. Penelitian Seddon \& Kiew (1996) mengungkapkan hasil yang seruoa bahwa kepuasan pengguna (user satisfaction) dapat dipengaruhi oleh kualitas sistem (system quality). Hasil penelitian yang diperoleh McKiney et al. (2002) dan McGill et al. (2003) menunjukkan bahwa kualitas sistem informasi berpengaruh positif terhadap kepuasan pemakainya. Kualitas sistem informasi yang semakin baik dengan memberikan fleksibility, kemudahan penggunaan (ease of use), keandalan sistem (reliability) akan meningkatkan minat penggunaan sistem informasi. Penelitian-penelitian yang menggunakan konstruk dari D\&M Success IS menunjukkan pengaruh positif antara kualitas sistem informasi pada minat penggunaan yaitu penelitian yang dilakukan Admaja (2014), Utami \& Samopa (2013), Supriyono (2017), Oktariyana (2019), dan Chen et al. (2016). Berbeda dengan penelitian yang dilakukan ole Nurlani \& Permana (2017) yang menunjukkan faktor teknologi yaitu kualitas informasi, kualitas sistem dan kualitas layanan tidak terbukti signifikan terhadap minat penggunaan.

Berdasarkan uraian diatas dikatakan bahwa jika pemakai sistem informasi percaya bahwa jika kualitas sistem informasi yang digunakan adalah baik, maka akan meningkatkan minat menggunakan sistem tersebut. Berdasarkan uraian tersebut maka dirumusakan hipotesis sebagai berikut.

$\mathrm{H}_{2}$ : Kualitas Sistem Informasi berpengaruh positif pada minat penggunaan internet banking.

Baridwan \& Hanum (2007) mengemukakan bahwa mutu pelayanan (Service quality) dapat diketahui dengan cara membandingkan persepsi para pelanggan atas pelayanan yang nyata-nyata mereka terima atau peroleh dengan pelayanan yang sesungguhnya mereka harapkan atau inginkan. Jika kenyataan lebih dari yang diharapkan, maka pelayanan dapat dikatakan bermutu. Sedangkan jika kenyataan kurang dari yang diharapkan, maka pelayanan dapat dikatakan tidak bermutu. Apabila kenyataan sama dengan harapan, maka pelayanan disebut memuaskan.

Susanto (2005) menjelaskan konsep kualitas layanan memenuhi harapan apabila pelayanan yang diharapkan sama dengna yang dirasakan artinya memuaskan bagi pengguna atas kualitas layanan yang diberikan oleh penyedia aplikasi software sistem informasi. Sedangkan Myers (1997) menyatakan bahwa kualitas layanan memiliki pengaruh terhadap kepuasan pengguna. Apabila pengguna sistem informasi merasakan bahwa kualitas layanan yang diberikan oleh penyedia paket program aplikasi akuntansi baik, maka ia akan cenderung 
untuk merasa puas menggunakan sistem tersebut. Diprediksi bahwa semakin tinggi kualitas layanan yang diberikan akan berpengaruh terhadap makin tingginya tingkat minat penggunaan.

Penelitian-penelitian yang menggunakan konstruk dari D\&M Success IS menunjukkan pengaruh positif antara kualitas layanan pada minat penggunaan yaitu penelitian yang dilakukan oleh Utami \& Samopa (2013), Supriyono (2017), Marselia et al. (2018) dan Oktariyana (2019). Berbeda dengan penelitian yang dilakukan oleh Nurlani \& Permana (2017) dan Admaja (2014) yang menunjukkan faktor teknologi, yaitu kualitas informasi, kualitas sistem, dan kualitas layanan tidak terbukti signifikan terhadap minat penggunaan. Berdasarkan uraian tersebut maka dirumuskan hipotesis sebagai berikut.

$\mathrm{H}_{3}$ : Kualitas layanan berpengaruh positif pada minat penggunaan internet banking.

Davis et al (1989) mengemukakan bahwa perilaku seseorang merupakan ekspresi dari keinginan atau minat seseorang dimana keinginan tersebut dipengaruhi faktor-faktor sosial, perasaan dan konsekuensi yang dirasakan mengemukakan bahwa adanya manfaat yang dirasakan oleh pemakai sistem informasi akan mningkatkan minat mereka untuk menggunakan sistem informasi.

Menurut Davis et al (1989), net benefits adalah keuntungan atau manfaat bersih yang dirasakan individu dan organisasi setelah menerapkan sistem informasi. Hubungan minat pemanfaatan, penggunaan sistem informasi, perilaku penggunaan teknologi informasi (use behavior) merupakan intensitas dan atau frekuensi pemakai dalam menggunakan teknologi informasi. Hubungan antara minat pemanfaatan sistem informasi dan penggunaan sistem informasi dikatakan positif apabila keinginan atau minat akan pemanfaatan sistem informasi yang ada pada seorang individu itu tinggi, maka akan tinggi pula manfaat bersih yang dirasakan individu dalam menggunakan sistem informasi tersebut. Berdasarkan uraian di atas, penelitian ini akan melihat sejauh mana dampak dari minat penggunaan sistem informasi terhadap net benefits. Penelitian-penelitian yang menggunakan konstruk dari D\&M menunjukkan pengaruh positif antara minat penggunaan pada net benefits yaitu penelitian yang dilakukan Munir \& Krisbiantoro (2020) serta Kumarahadi et al. (2020). Penelitian ini tidak menguji pengaruh mediasi dikarenakan peneliti tidak meneliti hubungan langusng antara pengaruh langsung kualitas sistem dan kualitas layanan terhadap net benefit. Berdasarkan uraian tersebut maka dirumuskan hipotesis sebagai berikut.

$\mathrm{H}_{4}$ : Minat penggunaan berpengaruh positif pada net benefits internet banking.

\section{METODE PENELITIAN}

Penelitian dilakukan pada perusahaan Perbankan di PT Bank Rakyat Indonesia Kota Denpasar. Alasan pemilihan lokasi penelitian di tempat ini karena di Kota Denpasar memiliki pertumbuhan ekonomi yang sangat pesat, sehingga dapat mempermudah nasabahnya khususnya nasabah yang berada di kota Denpasar dalam melakukan semua transaksi perbankan seperti transfer uang, cek saldo, akses produk perbankan seperti membuka tabungan berjangka, deposito, pinjaman KTA/KMG/KPR secara online dengan mudah dan cepat. 
Tabel 1. Indikator-indikator Kualitas Informasi

\begin{tabular}{|c|c|c|c|}
\hline & Indikator & Definisi & Sumber \\
\hline \multirow[t]{4}{*}{$\begin{array}{l}\text { Kualitas } \\
\text { informasi }\end{array}$} & Relevancy & $\begin{array}{l}\text { Informasi yang dihasilkan relevan dan } \\
\text { memiliki manfaat untuk pemakainya }\end{array}$ & $\begin{array}{l}\text { Rai et al. (2002); } \\
\text { DeLone \& } \\
\text { McLean (2003) }\end{array}$ \\
\hline & Accuracy & $\begin{array}{l}\text { Informasi yang dihasilkan akurat dan } \\
\text { bebas dari kesalahan }\end{array}$ & \\
\hline & Timeliness & Informasi yang dihasilkan tepat waktu & \\
\hline & Reliability & $\begin{array}{l}\text { Informasi yang dihasilkan dapat } \\
\text { dipercaya }\end{array}$ & \\
\hline \multirow{5}{*}{$\begin{array}{l}\text { Kualitas } \\
\text { Sistem } \\
\text { Informasi }\end{array}$} & Fleksibility & Kemampuan sistem informasi dalam & (DeLone \\
\hline & & melakukan perubahan-perubahan. & McLean, 2003) \\
\hline & & & Davis et al (1989) \\
\hline & $\begin{array}{l}\text { Kemudahan } \\
\text { penggunaan }\end{array}$ & $\begin{array}{l}\text { Kemudahan dan kenyamanan dalam } \\
\text { mengakses suatu teknologi. }\end{array}$ & \\
\hline & $\begin{array}{l}\text { Keandalan } \\
\text { sistem }\end{array}$ & $\begin{array}{l}\text { Sistem memiliki fungsi-fungsi yang } \\
\text { spesifik dan mudah dipahami. }\end{array}$ & \\
\hline \multirow{6}{*}{$\begin{array}{l}\text { Kualitas } \\
\text { Layanan }\end{array}$} & Tangibles & Fasilitas/peralatan layanan yang & DeLone \\
\hline & & $\begin{array}{l}\text { diberikan sistem sudah sesuai dengan } \\
\text { standar. }\end{array}$ & McLean (2003) \\
\hline & Kehandalan & $\begin{array}{l}\text { Layanan sesuai dengan apa yang } \\
\text { ditawarkan oleh penyedia software. }\end{array}$ & \\
\hline & $\begin{array}{l}\text { Responsivene } \\
\text { ss }\end{array}$ & $\begin{array}{l}\text { Sistem memberikan tanggapan sesuai } \\
\text { dengan apa yang diinginkan. }\end{array}$ & \\
\hline & Assurance & $\begin{array}{l}\text { Keamanan dalam mengakses atau } \\
\text { mengirim data menggunakan sistem. }\end{array}$ & \\
\hline & Empaty & $\begin{array}{l}\text { Sistem memberikan layanan bantuan } \\
\text { dan beberapa masukan yang } \\
\text { memudahkan penggunaan sistem. }\end{array}$ & \\
\hline \multirow{4}{*}{$\begin{array}{l}\text { Minat } \\
\text { Pengguna } \\
\text { an }\end{array}$} & Mempunyai & Pengguna selalu mencoba & (Jogiyanto, 2007) \\
\hline & $\begin{array}{l}\text { fitur yang } \\
\text { membantu }\end{array}$ & $\begin{array}{l}\text { menggunakan sistem untuk membantu } \\
\text { mengerjakan pekerjaan dengan fitur- } \\
\text { fitur yang ada. }\end{array}$ & Davis (1989) \\
\hline & $\begin{array}{l}\text { Selalu } \\
\text { mencoba } \\
\text { menggunak } \\
\text { an }\end{array}$ & $\begin{array}{l}\text { Pengguna selalu mencoba } \\
\text { menggunakan sistem sesering mungkin } \\
\text { untuk meningkatkan pengetahuan. }\end{array}$ & \\
\hline & $\begin{array}{l}\text { Berlanjut di } \\
\text { masa } \\
\text { datang }\end{array}$ & $\begin{array}{l}\text { Pengguna mengharapkan bisa terus } \\
\text { menggunakan sistem dikemudian hari. }\end{array}$ & \\
\hline \multirow[t]{4}{*}{$\begin{array}{l}\text { Net } \\
\text { benefits }\end{array}$} & $\begin{array}{l}\text { Speed of } \\
\text { accomplishin } \\
\text { g task }\end{array}$ & $\begin{array}{l}\text { Pengguna dapat lebih cepat dalam } \\
\text { melakukan transaski }\end{array}$ & Davis et al. (1989) \\
\hline & Effectiveness & $\begin{array}{l}\text { Pengguna lebih efektif dalam } \\
\text { bertransaksi }\end{array}$ & \\
\hline & Ease of job & $\begin{array}{l}\text { Mempermudah pengguna dalam proses } \\
\text { transaksi }\end{array}$ & \\
\hline & $\begin{array}{l}\text { Usefulness in } \\
\text { work }\end{array}$ & $\begin{array}{l}\text { Manfaat atau kegunaan menggunkanan } \\
\text { system dalam bekerja }\end{array}$ & \\
\hline
\end{tabular}

Sumber: Davis et al., 1989; DeLone \& McLean, 2003; Jogiyanto, 2007; Rai et al., 2002 
Kualitas informasi merupakan kualitas output yang berupa informasi yang dihasilkan oleh sistem informasi yang digunakan. Instrumen-instrumen yang digunakan untuk mengukur kualitas informasi adalah atribut yang digunakan oleh yang terdiri dari 4 indikator pertanyaan yang menunjukkan kualitas informasi yang ditunjukkan oleh minat penggunaan internet banking. Indikatorindikator kualitas informasi tersaji pada Tabel 1.

Pengujian hipotesis pada penelitian ini menggunakan PLS (Partial Least Square) yaitu analisis persamaan structural (SEM) berbasis varians yang secara simultan dapat melakukan pengujian model pengukuran sekaligus pengujian model structural (Abdillah \& Hartono, 2016). Diagram jalur yang diterjemahkan menjadi persamaan untuk structural model dan measurement model, yaitu.

$$
\begin{aligned}
& \eta_{1}=\gamma_{1} \xi_{1}+\gamma_{2} \xi_{2}+\gamma_{3} \xi_{3}+\zeta_{1} \\
& \eta_{2}=\beta_{1} \eta_{1}+\zeta_{2}
\end{aligned}
$$

Keterangan:

$\xi(\mathrm{ksi}) \quad=$ Variabel laten eksogen

$\xi_{1} \quad=$ Kualitas Informasi (Information Quality)

$\xi_{2} \quad=$ Kualitas Sistem Informasi (Information System Quality)

$\xi_{3} \quad=$ Kualitas Layanan (Service Quality)

$\eta$ (eta) $=$ Variabel Endogen

$\eta_{1} \quad=$ Minat Penggunaan

$\eta_{2} \quad=$ Net benefits

$\gamma($ gama $)=$ Koefisien pengaruh variabel eksogen terhadap variabel endogen

$\beta$ (beta) = Koefisien pengaruh variabel endogen terhadap endogen

$\zeta$ (zeta) = Koefisien dalam persamaan yaitu antara variabel eksogen dan/atau variabel Endogen terhadap variabel endogen

\section{HASIL DAN PEMBAHASAN}

Sampel penelitian terdiri atas 14 PT Bank Rakyat Indonesia Kota Denpasar. Data dikumpulkan melalui dua tahap yaitu tahap pertama mengumpulkan, yaitu mengumpulkan jumlah partisipan dalam menggunakan internet banking di 14 PT Bank Rakyat Indonesia Kota Denpasar. Tahap kedua, mengirimkan kuesioner yang ditujukan kepada pengguna internet banking di PT Bank BRI di Kota Denpasar. Penyebaran kuesioner dilakukan pada 16 juni 2021 sampai 2 juli 2021. Responden dalam penelitian ini berjumlah 150 partisipan.

Karakteristik responden ini merupakan data yang dikumpulkan untuk mengetahui profil responden dalam penelitian yang didapatkan dari kuesioner. Karakteristik responden dalam penelitian ini meliputi jenis kelamin, lama bekerja, pendidikan terakhir. Karakteristik responden dapat dilihat pada Tabel 2.

Adapun karakteristik responden cukup beragam, komposisi jenis kelamin laki-laki sebanyak 63 orang (42\%) dan perempuan sebanyak 87orang (58\%). Usia $<30$ Tahun sebanyak 59 orang (39\%) dan usia > 30 tahun sebanyak 91 orang (61\%). Sampel yang digunakan sebagai responden memiliki tingkat pendidikan sarjana srata SMA sebanyak 42 orang (28\%), S1 sebanyak 66 orang (44\%), S2 sebanyak 26 orang $(17 \%)$, S3 sebanyak 16 orang $(11 \%)$. 
Tabel 2. Karakteristik Responden

\begin{tabular}{|c|c|c|c|}
\hline \multirow{2}{*}{ No } & \multirow{2}{*}{ Karakteristik Responden } & \multicolumn{2}{|c|}{ Jumlah } \\
\hline & & Orang & Persentase (\%) \\
\hline A & Jenis Kelamin & & \\
\hline 1 & Laki-Laki & 63 & $42 \%$ \\
\hline 2 & Perempuan & 87 & $58 \%$ \\
\hline & Total & 150 & 100,00 \\
\hline B & Usia & & \\
\hline 1 & $\leq 30$ Tahun & 59 & $39 \%$ \\
\hline 2 & >30Tahun & 91 & $61 \%$ \\
\hline & Total & 150 & 100,00 \\
\hline C & Pendidikan Terakhir & & \\
\hline 1 & SMA & 42 & $28 \%$ \\
\hline 2 & S1 & 66 & $44 \%$ \\
\hline 3 & S2 & 26 & $17 \%$ \\
\hline 3 & S3 & 16 & $11 \%$ \\
\hline & Total & 150 & 100,00 \\
\hline
\end{tabular}

Sumber: Data Penelitian, 2021

Hasil pengujian statistik deskriptif disajikan pada Tabel 2, menjelaskan statistik deskriptif dari variabel-variabel penelitian dengan jumlah pengamatan sebanyak 150 sampel.

Tabel 3. Statistik Deskriptif

\begin{tabular}{lccccc}
\hline & $\mathrm{N}$ & Minimum & Maximum & Mean & Std. Deviation \\
\hline X1.1 & 150 & 2,00 & 5,00 & 4,000 & 0,955 \\
X1.2 & 150 & 2,00 & 5,00 & 3,986 & 0,912 \\
X1.3 & 150 & 2,00 & 5,00 & 3,800 & 1,023 \\
X1.4 & 150 & 2,00 & 5,00 & 4,000 & 0,897 \\
Kualitas Informasi & 150 & 2,00 & 5,00 & 3,946 & 0,837 \\
X2.1 & 150 & 2,00 & 5,00 & 3,973 & 0,904 \\
X2.2 & 150 & 2,00 & 5,00 & 3,933 & 0,856 \\
X2.3 & 150 & 2,00 & 5,00 & 3,966 & 0,830 \\
Kualitas & 150 & 2,00 & 5,00 & 3,957 & 0,781 \\
Informasi & & & & & \\
X3.1 & 150 & 2,00 & 5,00 & 3,806 & 0,887 \\
X3.2 & 150 & 2,00 & 5,00 & 3,826 & 0,910 \\
X3.3 & 150 & 2,00 & 5,00 & 4,093 & 0,813 \\
X3.4 & 150 & 2,00 & 5,00 & 3,980 & 0,789 \\
X3.5 & 150 & 2,00 & 5,00 & 3,920 & 0,855 \\
Kualitas Layanan & 150 & 2,00 & 5,00 & 3,925 & 0,746 \\
Y1.1 & 150 & 2,00 & 5,00 & 3,946 & 0,833 \\
Y1.2 & 150 & 2,00 & 5,00 & 3,986 & 0,759 \\
Y1.3 & 150 & 2,00 & 5,00 & 4,053 & 0,849 \\
Minat Pengguna & 150 & 2,00 & 5,00 & 3,995 & 0,732 \\
Y2.1 & 150 & 2,00 & 5,00 & 3,833 & 0,763 \\
Y2.2 & 150 & 2,00 & 5,00 & 3,946 & 0,712 \\
Y2.3 & 150 & 2,00 & 5,00 & 3,920 & 0,923 \\
Y2.4 & 150 & 2,00 & 5,00 & 4,026 & 0,874 \\
Net benefits & 150 & 2,00 & 5,00 & 3,931 & 0,722 \\
\hline Sum & & & &
\end{tabular}

Sumber: Data Penelitian, 2021 
Variabel kualitas informasi memiliki nilai rata-rata (mean) sebesar 3,946 dengan nilai minimum sebesar 2,00, nilai maksimum sebesar 5,00, dan nilai standar deviasi sebesar 0,837. Penilaian jawaban responden pada kualitas infromasi mendapatkan skor mean sebesar 3,946 yang menunjukkan bahwa tingkat kualitas infromasi penggunaan internet banking PT Bank Rakyat Indonesia Kota Denpasar tergolong memuaskan.

Variabel kualitas sistem informasi memiliki nilai rata-rata (mean) sebesar 3,957 dengan nilai minimum sebesar 2,00, nilai maksimum sebesar 5,00, dan nilai standar deviasi sebesar 0,781. Penilaian jawaban responden pada kualitas sistem informasi mendapatkan skor mean sebesar 3,957 yang menunjukkan bahwa tingkat kualitas sistem informasi penggunaan internet banking PT Bank Rakyat Indonesia Kota Denpasar tergolong memuaskan.

Variabel kualitas layanan memiliki nilai rata-rata (mean) sebesar 3,925 dengan nilai minimum sebesar 2,00, nilai maksimum sebesar 5,00, dan nilai standar deviasi sebesar 0,746. Penilaian jawaban responden pada kualitas layanan mendapatkan skor mean sebesar 3,925 yang menunjukkan bahwa tingkat kualitas layanan penggunaan internet banking PT Bank Rakyat Indonesia Kota Denpasar tergolong memuaskan.

Variabel minat pengguna memiliki nilai rata-rata (mean) sebesar 3,995 dengan nilai minimum sebesar 2,00, nilai maksimum sebesar 5,00, dan nilai standar deviasi sebesar 0,732. Penilaian jawaban responden pada minat pengguna mendapatkan skor mean sebesar 3,995 yang menunjukkan bahwa minat penggunaan internet banking PT Bank Rakyat Indonesia Kota Denpasar tergolong memuaskan.

Variabel net benefits memiliki nilai rata-rata (mean) sebesar 3,931 dengan nilai minimum sebesar 2,00, nilai maksimum sebesar 5.00, dan nilai standar deviasi sebesar 0,722. Penilaian jawaban responden pada net benefits mendapatkan skor mean sebesar 3,931 yang menunjukkan bahwa net benefits penggunaan internet banking PT Bank Rakyat Indonesia Kota Denpasar tergolong memuaskan.

Convergent validity dengan indikator refleksif dapat dilihat dari korelasi antara skor indikator dengan skor variabelnya. Indikator individu dianggap reliabel apabila memiliki nilai korelasi diatas 0,50. Hasil korelasi antara dimensi dengan variabelnya dapat dilihat pada Tabel 3.

Berdasarkan Tabel 4, menunjukkan bahwa seluruh nilai outer loading indikator memiliki nilai diatas 0,50. Dengan demikian, dapat disimpulkan bahwa pengukuran convergent validity telah memenuhi persyaratan convergent validity. Metode lain untuk menilai discriminant validity adalah dengan membandingkan akar kuadrat dari average variance extracted $(\sqrt{\mathrm{AVE}})$ untuk setiap variabel dengan korelasi antara variabel dengan variabel lainnya dalam model. Model mempunyai discriminant validity yang cukup jika akar kuadrat AVE untuk setiap variabel lebih besar daripada korelasi antara variabel dan variabel lainnya dalam model.

Seluruh variabel dalam model yang diuji memenuhi kriteria discriminant validity. Pengujian discriminant validity dapat dilihat dengan cara menilai validitas dari variabel pada nilai AVE. Model dikatakan baik jika AVE masing-masing variabel nilainya lebih besar dari 0,50 . Hasil output menunjukkan bahwa nilai AVE seluruh variabel lebih besar dari 0,50 sehingga model dapat dikatakan valid. 
Tabel 4. Hasil Pengujian Validitas dan Reliabilitas

\begin{tabular}{|c|c|c|c|c|}
\hline Konstruk & Indikator & Outer Loading & AVE & $\begin{array}{c}\text { Cronbach's } \\
\text { Alpha }\end{array}$ \\
\hline \multirow{4}{*}{ Kualitas Informasi } & X1.1 & 0,902 & \multirow{4}{*}{0,690} & \multirow{5}{*}{0,848} \\
\hline & $\mathrm{X} 1.2$ & 0,828 & & \\
\hline & $\mathrm{X} 1.3$ & 0,844 & & \\
\hline & X1.4 & 0,741 & & \\
\hline \multirow{3}{*}{ Kualitas Sistem Informasi } & X2.1 & 0,896 & \multirow{4}{*}{0,800} & \\
\hline & $\mathrm{X} 2.2$ & 0,880 & & \multirow[t]{2}{*}{0,875} \\
\hline & $\mathrm{X} 2.3$ & 0,907 & & \\
\hline \multirow{5}{*}{ Kualitas Pelayanan } & X3.1 & 0,834 & & \multirow{5}{*}{0,907} \\
\hline & X3.2 & 0,864 & \multirow{4}{*}{0,729} & \\
\hline & X3.3 & 0,880 & & \\
\hline & X3.4 & 0,846 & & \\
\hline & X3.5 & 0,835 & & \\
\hline \multirow{3}{*}{ Minat Pengguna } & Y1.1 & 0,864 & \multirow{3}{*}{0,724} & \multirow{3}{*}{0,810} \\
\hline & Y1.2 & 0,813 & & \\
\hline & Y1.3 & 0,873 & & \\
\hline \multirow{4}{*}{ Net benefit } & Y2.1 & 0,904 & \multirow{4}{*}{0,734} & \multirow{4}{*}{0,879} \\
\hline & Y2.2 & 0,820 & & \\
\hline & Y2.3 & 0,818 & & \\
\hline & Y2.4 & 0,882 & & \\
\hline
\end{tabular}

Sumber: Data Penelitian, 2021

Selain uji validitas, juga dilakukan uji reliabilitas variabel yang diukur dengan dua kriteria, yaitu composite reliability dan cronbachs alpha dari blok indikator yang mengukur variabel. Variabel dinyatakan reliabel jika nilai composite reliability maupun cronbachs alpha diatas 0,70. Hasil output composite reliability maupun cronbachs alpha seluruh variabel penelitian semuanya diatas 0,70 . Dengan demikian, dapat dijelaskan bahwa seluruh variabel adalah reliabel.

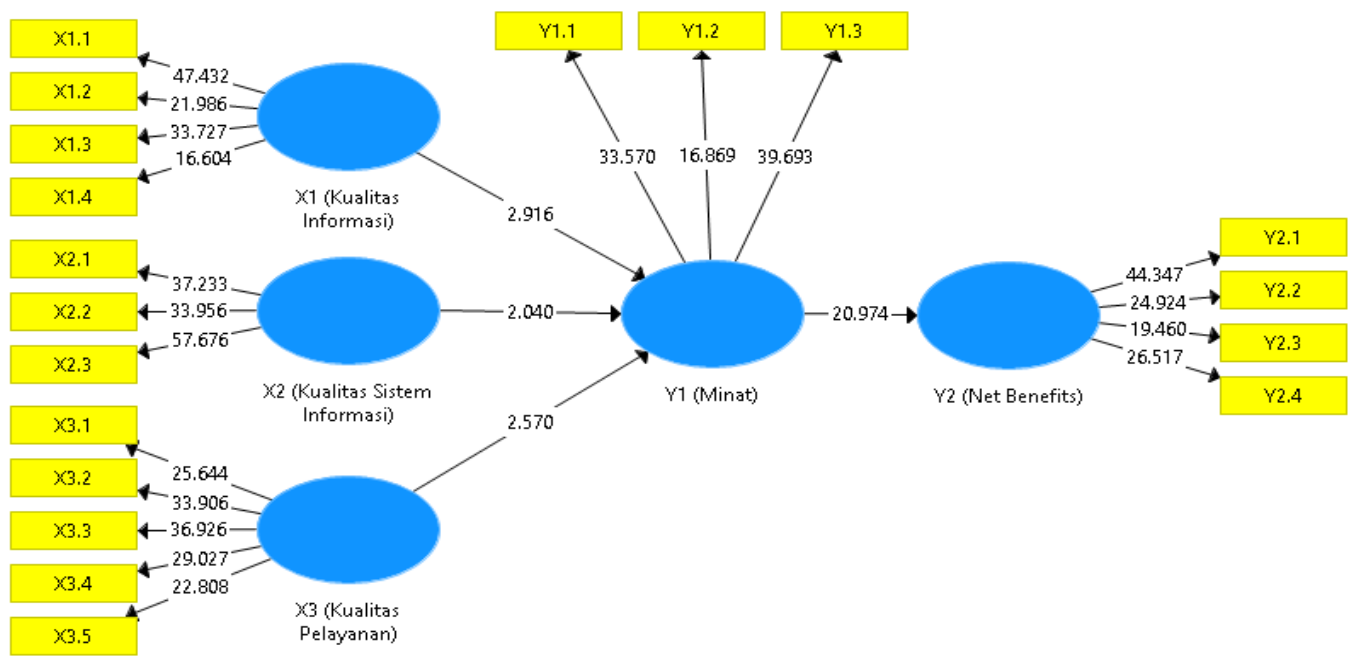

Gambar 2. Boothstarpping (Uji Statistik) Variabel Penelitian

Sumber: Data Penelitian, 2021

Dalam model struktural ini, terdapat dua variabel endogen, yaitu: minat pengguna dan net benefit. Model pengaruh kualitas informasi, kualitas sistem informasi dan kualitas layanan pada minat penggunaan internet banking, 
memberikan nilai R-square sebesar 0,696 yang dapat diinterpretasikan bahwa variabilitas variabel minat penggunaan internet banking dapat dijelaskan oleh kualitas informasi, kualitas sistem informasi dan kualitas layanan sebesar 69,6 persen, sedangkan 30,4 persen sisanya dijelaskan oleh variabel lain diluar yang diteliti.

Model pengaruh minat penggunaan internet banking pada net benefit memberikan nilai R-square sebesar 0,689 yang dapat diinterpretasikan bahwa variabilitas variabel net benefit dapat dijelaskan oleh variabilitas variabel minat penggunaan sebesar 68,9 persen, sedangkan sisanya sebesar 31,1 persen dijelaskan oleh variabel lain diluar yang diteliti.

Hasil uji validasi koefisien path pada setiap jalur untuk pengaruh langsung dan efek dapat disajikan pada Tabel 5.

\section{Tabel 5. Hasil Pengujian Efek Langsung}

\begin{tabular}{|c|c|c|c|c|c|}
\hline No. & $\begin{array}{c}\text { Hubungan Antar } \\
\text { Variabel }\end{array}$ & $\begin{array}{l}\text { Koefisien Jalur } \\
\text { (Bootstrapping) }\end{array}$ & $\begin{array}{c}\mathrm{T} \\
\text { Statistic }\end{array}$ & $\begin{array}{c}\mathrm{P} \\
\text { Value }\end{array}$ & Keterangan \\
\hline 1. & Kualitas Informasi $\rightarrow$ Minat & 0,313 & 2,916 & 0,004 & Signifikan \\
\hline 2. & $\begin{array}{c}\text { Kualitas Sistem Informasi } \rightarrow \\
\text { Minat }\end{array}$ & 0,246 & 2,040 & 0,042 & Signifikan \\
\hline 3. & Kualitas Pelayanan $\rightarrow$ Minat & 0,34 & 2,570 & 0,010 & \\
\hline 4. & Minat $\rightarrow$ Net benefit & 0,830 & 20,974 & 0,000 & Signifikan \\
\hline
\end{tabular}

Sumber: Data Penelitian, 2021

Kualitas informasi berpengaruh positif pada minat penggunaan internet banking di PT Bank Rakyat Indonesia Kota Denpasar. Koefisien jalur bernilai positif memiliki arti bahwa semakin tinggi tingkat kualitas informasi, maka minat penggunaan internet banking akan semakin meningkat. Hal ini berarti semakin baik kualitas informasi yang didapat oleh pengguna internet banking maka minat dari penggunaan internet banking tersebut akan meningkat, sehingga memberikan informasi yang baik kepada pengguna akan berdampak pada meningkatnya minat penggunaan. Hasil penelitian ini didukung oleh hasil penelitian Admaja (2014), Utami \& Samopa (2013), Supriyono (2017) dan Oktariyana (2019), Manoharan et al. (2021) yang membuktikan kualitas informasi berpengaruh positif pada minat penggunaan.

Kualitas informasi merupakan sejauh mana informasi secara konsisten dapat memenuhi persyaratan dan harapan semua orang yang membutuhkan informasi tersebut untuk melakukan proses mereka. Hasil informasi yang diberikan internet banking memberikan data yang relevan, akurat, tepat waktu dan reliabel pada penggunanya. Responden memberi jawaban tertinggi pada indikator relevancy dan reliability dengan nilai mean sebesar 4,00. Hal ini menunjukkan internet banking sangat relevan dan reliabel. Tingginya kualitas informasi yang dihasilkan internet banking memberikan dampak positif pada minat penggunaan sehingga pengguna akan terus menggunakan sistem tersebut.

Kualitas sistem informasi berpengaruh positif pada minat penggunaan internet banking di PT Bank Rakyat Indonesia Kota Denpasar. Koefisien jalur bernilai positif memiliki arti bahwa semakin tinggi tingkat kualitas sistem informasi, maka minat penggunaan internet banking akan semakin meningkat. Hal ini berarti semakin baik sistem informasi di suatu perbankan, akan meningkatkan minat nasabah dalam menggunakan internet banking. Hal ini mencerminkan 
bahwa setiap perbankan sudah seharusnya menciptakan sistem informasi yang baik guna meningkatkan minat penggunaan internet banking. Hasil penelitian ini didukung oleh hasil penelitian Thaker et al. (2021), Yeşildağ (2019), Admaja (2014), Utami \& Samopa (2013), Supriyono (2017) dan Oktariyana (2019) membuktikan kualitas sistem informasi berpengaruh positif pada minat penggunaan.

Kualitas sistem adalah pengukuran proses sistem informasi yang berfokus pada hasil interaksi antara pengguna dan sistem. Kualitas sistem mempunyai atribut-atribut seperti fleksibel, kemudahan penggunaan dan keandalan sistem yang merupakan faktor penentu mengapa sebuah sistem informasi digunakan atau tidak digunakan. Jika faktor penentu tersebut terpenuhi maka sistem yang diterapkan akan meningkatkan minat pemakainya untuk menggunakan sistem tersebut secara terus menerus.

Responden memberi jawaban tertinggi pada indikator fleksibility dengan nilai mean sebesar 3,97 yang berarti internet banking telah memenuhi harapan dari penggunanya dengan memberikan fleksibility, kemudahan penggunaan dan keandalan sistem. Hal ini menunjukkan internet banking memiliki kemampuan sistem informasi dalam melakukan perubahan-perubahan kaitannya dengan kebutuhan pengguna sistem, sehingga memenuhi harapan pengguna sistem yang berdampak pada pengguna akan tetap menggunakan internet banking dalam menunjang kegiatannya.

Kualitas layanan berpengaruh positif pada minat penggunaan internet banking di PT Bank Rakyat Indonesia Kota Denpasar. Koefisien jalur bernilai positif memiliki arti bahwa semakin tinggi tingkat kualitas layanan yang diberikan, maka minat penggunaan internet banking akan semakin meningkat. Hal ini berarti semakin baik kualitas layanan dari suatu perbankan akan meningkatkan minat dari penggunaan internet banking, sehingga hal ini sudah sewajarnya bagi perbankan dalam menciptakan kualitas layanan yang baik guna meningkatkan minat penggunaan internet banking. Hasil penelitian ini didukung oleh hasil penelitian Utami \& Samopa (2013), Supriyono (2017) membuktikan kualitas layanan berpengaruh positif pada minat penggunaan.

Konsep kualitas layanan memenuhi harapan apabila pelayanan yang diharapkan sama dengan yang dirasakan artinya apabila nasabah merasa kualitas layanan dari internet banking itu baik dengan kelengkapan fitur yang menarik, maka akan mempengaruhi minat nasabah untuk menggunakan internet banking

Responden memberi jawaban tertinggi pada indikator Responsiveness dengan nilai mean sebesar 4,09 yang berarti pengguna merasa internet banking memberikan tanggapan sesuai dengan apa yang diinginkan. Fitur dari kualitas layanan yang diberikan internet banking memenuhi harapan dari nasabah PT Bank Rakyat Indonesia Kota Denpasar. Layanan ini menyebabkan pengguna merasa puas atas layanan internet banking dan meningkatkan minat penggunaan internet banking secara berkelanjutan.

Minat penggunaan berpengaruh positif pada net benefit di PT Bank Rakyat Indonesia Kota Denpasar. Koefisien jalur bernilai positif memiliki arti bahwa semakin tinggi minat penggunaan, maka keuntungan atau manfaat bersih akan semakin meningkat. Hal ini berarti semakin tinggi minat penggunaan internet banking semakin baik juga net benefit yang dirasakan oleh pengguna. Hasil penelitian ini didukung oleh hasil penelitian dilakukan Safari et al (2020), Naeem 
(2020), Munir \&c Krisbiantoro (2020) serta Kumarahadi, et al. (2020) membuktikan minat penggunaan berpengaruh pada net benefits.

Hubungan antara minat penggunaan sistem informasi dan penggunaan sistem informasi dikatakan positif apabila keinginan atau minat akan pemanfaatan sistem informasi yang ada pada seorang individu itu tinggi, maka akan tinggi pula manfaat bersih yang dirasakan individu dalam menggunakan sistem informasi tersebut. Net benefits adalah keuntungan atau manfaat bersih yang dirasakan individu dan organisasi setelah menerapkan sistem informasi.

Responden memberi jawaban tertinggi pada indikator berlanjut di masa datang dengan nilai mean sebesar 4,05 yang berarti pengguna mengharapkan bisa terus menggunakan internet banking dalam keseharianya. Internet banking setelah diimplementasikan pengguna telah mengetahui kelemahan dan kelebihan yang dirasakan. Banyak kelebihan yang diberikan dibandingkan kelemahan setelah implementasi internet banking, sehingga meningkatkan minat penggunaan sistem secara terus menerus dan berdampak positif pada keuntungan atau manfaat bersih dari nasabah PT Bank Rakyat Indonesia Kota Denpasar.

\section{SIMPULAN}

Kualitas informasi berpengaruh positif pada minat penggunaan internet banking. Hal ini menunjukkan bahwa semakin baik kualitas informasi yang dihasilkan, maka minat penggunaan internet banking semakin meningkat. Kualitas sistem informasi berpengaruh positif pada minat penggunaan internet banking. Hal ini menunjukkan bahwa semakin baik kualitas sistem informasi yang dihasilkan, maka minat penggunaan internet banking semakin meningkat. Kualitas layanan berpengaruh positif pada minat penggunaan internet banking. Hal ini menunjukkan bahwa semakin baik kualitas layanan yang diberikan, maka minat penggunaan internet banking semakin meningkat. Minat penggunaan internet banking berpengaruh positif pada net benefit. Hal ini menunjukkan bahwa semakin tinggi minat penggunaan internet banking, maka keuntungan atau manfaat bersih semakin meningkat.

Hasil penelitian ini memberikan kontribusi bagi PT Bank Rakyat Indonesia Kota Denpasar, karena hasil dari statistik deskriptif penelitian menunjukkan jawaban responden yang baik, terdapat variabel kualitas layanan yang jawaban respondennya harus ditingkatkan kembali oleh PT Bank Rakyat Indonesia Kota Denpasar, yang akan mempengaruhi minat nasabah untuk menggunakan internet banking. Keterbatasan penelitian ini hanya dilakukan pada PT Bank Rakyat Indonesia Kota Denpasar sehingga tidak dapat digeneralisasikan pada kondisi lingkungan atau perusahaan yang berbeda, sehingga penelitian selanjutnya dapat dilakukan dengan menggunakan subjek yang berbeda dan jangkauan dari penelitian selanjutnya dapat lebih luas.

Penelitian ini berkontribusi secara teoritis dan praktis, secara teoritis penelitian ini menambah literatur baru terkait factor-faktor yang mempengaruhi net benefit, secara praktis penelitian ini dapat memberikan tamabahan informasi kepada manajemen perbankan terkait layanan internet banking yang diberikan seperti memperhatikan kualitas layanan, kesediaan sistem informasi yang baik dan kualitas informasi yang akurat demi manfaat yang diterima oleh pengguna internet banking. 


\section{REFERENSI}

Abdillah, W., \& Hartono, J. (2016). Partial Least Square (PLS) Alternatif Structural Equation Modeling (SEM) dalam Penelitian Bisnis. Andi Offset.

Admaja, A. F. S. (2014). Analisis Kesuksesan Sistem Informasi Manajemen Sumber Daya dan Perangkat Pos dan Informatika ( SIMS ) An Analysis of Information System Success Success for SIMS An Analysis of Information System Success ( Sistem Informasi Manajemen SDPPI ). Buletin Pos Dan Telekomunikasi, 12(2), 105-118.

Baridwan, Z., \& Hanum, L. (2007). Kualitas Dan Efektivitas Sistem Informasi Berbasis Komputer. Universitas Brawijaya.

Buchholz, W., \& Rübbelke, D. (2020). Overstraining International Climate Finance: When Conflicts of Objectives Threaten Its Success. SSRN Electronic Journal, 13(4/5), 547-563. https:// doi.org/10.2139/ssrn.3726032

Chen, J. F., Chang, J. F., Kao, C. W., \& Huang, Y. M. (2016). Integrating ISSM into TAM to enhance digital library services: A case study of the Taiwan digital meta-library. Electronic Library, 34(1), 58-73. https:/ / doi.org/10.1108/EL-012014-0016

Davis, F. D., Bagozzi, R. P., \& Warshaw, P. R. (1989). User Acceptance of Computer Technology: A Comparison of Two Theoretical Models. Management Science, 35. https:// doi.org/10.1287/mnsc.35.8.982

DeLone, W. H., \& McLean, E. R. (1992a). Information systems success: The quest for the dependent variable. Information Systems Research. https:// doi.org/10.1287/isre.3.1.60

DeLone, W. H., \& McLean, E. R. (1992b). Information systems success: The quest for the dependent variable. Information Systems Research. https://doi.org/10.1287/isre.3.1.60

DeLone, W. H., \& McLean, E. R. (2003). The DeLone and McLean model of information systems success: A ten-year update. Journal of Management Information Systems, 19(4), 9-30. https://doi.org/10.1080/07421222.2003.11045748

Dewi, R. I. (2016). Pengaruh E-Banking dan Kualitas Pelayanan terhadap Loyalitas Nasabah pada PT. Bank BNI'46 Cabang Langsa. Jurnal Manajemen Dan Keuangan Unsam, 5(2).

Hendarti, H., \& Gui, A. (2008). Korelasi Antara Efektifitas Sistem Informasi Penjualan Dengan Kinerja User. Simposium Nasional Akuntansi(SNA) KE XI Pontianak, 2008(Snati).

Jogiyanto. (2007). Sistem Informasi Keperilakuan. Yogyakarta: BPFE Yogyakarta, edisi ke enam.

Lau, C. K., \& Chen, H. (2021). Stakeholder perceptions on the risk factors, challenges and benefits of business sustainability practices in the Singapore construction industry. Property Management, Ahead-Of-P(Ahead-Of-Print). https:// doi.org/10.1108/PM-02-2021-0014

Manoharan, S., Katuk, N., Hassan, S., \& Ahmad, R. (2021). To click or not to click the link: the factors influencing internet banking users' intention in responding to phishing emails. Information and Computer Security, Ahead of P(Ahead of Print). https:/ / doi.org/10.1108/ICS-04-2021-0046

McGill, T. ., Hobbs, V. ., \& Klobas, J. (2003). User developed applications and 
information systems success: A test of DeLone and McLean's model. Information Resources Management. https:/ / doi.org/10.4018/irmj.2003010103

McKiney, V., Yoon, K., \& Fatemeh. (2002). The measurement of Web-customer satisfaction: an expectation and disconfirmation approach. Information Systems Research, 13(3), 296-315. https://doi.org/10.1287/isre.13.3.296.76

Myers, M. D. (1997). Qualitative Research in Information Systems. MIS Quarterly. https://doi.org/10.2307/249422

Naeem, M. (2021). Developing the antecedents of social influence for Internet banking adoption through social networking platforms: evidence from conventional and Islamic banks. Asia Pacific Journal of Marketing and Logistics, 33(1), 185-204. https:// doi.org/10.1108/APJML-07-2019-0467

Nurlani, L., \& Permana, B. (2015). Analisa Kesuksesan Sistem Informasi Akademik Menggunakan Model Terintegrasi. Jurnal Teknologi Rekayasa, 2(2), 105-116. https://doi.org/http://dx.doi.org/10.31544/jtera.v2.i2.2017.105-116

Rai, A., Lang, S.S., dan Welker, R. B. (2002). Assesing the validity of IS Succes Models: An Empirical Test and Theoretical Analysis. Information Systems Research. ABI/INFORM Global, (May 2014), pp.50-113. https://doi.org/10.1287/isre.13.1.50.96

Rithmaya, C. L. (2016). Pengaruh Kemudahan Penggunaan, Kemanfaatan, Sikap, Risiko Dan Fitur Layanan Terhadap Minat Ulang Nasabah Bank Bca Dalam Menggunakan Initernet Banking. Jurnal Riset Ekonomi Dan Manajemen, 16, 160. https://doi.org/10.17970/jrem.16.160110.id

Rukmiyati, N. M. S., \& Budiartha, I. K. (2016). Pengaruh kualitas sistem informasi, kualitas informasi dan perceived usefulness pada kepuasan pengguna akhir software akuntansi (studi empiris pada hotel .... E-Jurnal Ekonomi Dan Bisnis ..., 5(1), 115-142.

Safari, K., Bisimwa, A., \& Buzera Armel, M. (2020). Attitudes and intentions toward internet banking in an under developed financial sector. PSU Research Review, Ahead of P(Ahead of Print). https://doi.org/10.1108/prr-03-20200009

Seddon, P., \& Kiew, M.-Y. (1996). A Partial Test and Development of Delone and Mclean's Model of IS Success. Australasian Journal of Information Systems, 4(1), 90-109. https:// doi.org/10.3127/ajis.v4i1.379

Sugiyono. (2016). Metode Penelitian Kuantitatif, Kualitatif dan Kombinasi (Mixed Methods). Bandung: Alfabeta. https://doi.org/Doi 10.1016/J.Datak.2004.11.010

Supriyono. (2017). Analisis Kesuksesan Sistem Informasi Perpustakaan Di Universitas Negeri Yogyakarta (UNY) Dengan Pendekatan Model Delone Dan Mclean. Pendidikan Teknik Informatika, (1), 1-10.

Thaker, H. M. T., Asmy, M., Khaliq, A., Allah Pitchay, A., \& Iqbal Hussain, H. (2021). Behavioural intention and adoption of internet banking among clients' of Islamic banks in Malaysia: an analysis using UTAUT2. Journal of Islamic Marketing, Ahead of P(Ahead of Print). https://doi.org/10.1108/JIMA-112019-0228

Utami, A. W., \& Samopa, F. (2013). Analisa Kesuksesan Sistem Informasi Akademik di Perguruan Tinggi dengan Menggunakan D \&amp; M IS Success Model (Studi Kasus: ITS Surabaya). Sisfo, 4(5), 294-309. 
https:// doi.org/10.24089/j.sisfo.2013.09.001

Yeşildağ, E. (2019). Factors affecting internet banking preferences and their relation to demographic characteristics. In Contemporary Studies in Economic and Financial Analysis. https:// doi.org/10.1108/S1569-375920190000101013 